\title{
HER2 Gene Amplification in ER-positive HER2 Immunohistochemistry 0 or 1+ Breast Cancer With Early Recurrence
}

\author{
HIROKO YAMASHITA ${ }^{1}$, NAOKO ISHIDA ${ }^{1}$, YUTAKA HATANAKA ${ }^{2,3}$, KANAKO HAGIO $^{1}$, \\ TOMOHIRO OSHINO ${ }^{1}$, TAKASHI TAKESHITA ${ }^{1}$, HIROMI KANNO-OKADA ${ }^{3}$, \\ AI SHIMIZU ${ }^{3}$, KANAKO C. HATANAKA ${ }^{2,3}$ and YOSHIHIRO MATSUNO ${ }^{2,3}$ \\ ${ }^{1}$ Department of Breast Surgery, Hokkaido University Hospital, Sapporo, Japan; \\ ${ }^{2}$ Research Division of Companion Diagnostics, Hokkaido University Hospital, Sapporo, Japan; \\ ${ }^{3}$ Department of Surgical Pathology, Hokkaido University Hospital, Sapporo, Japan
}

\begin{abstract}
Background/Aim: In estrogen receptor (ER)positive, human epidermal growth factor receptor 2 (HER2)negative breast cancer, standard chemotherapies as well as adjuvant endocrine therapy might not be enough for prevention of early relapse. Materials and Methods: We focused on ERpositive, HER2 immunohistochemistry (IHC) 0 or $1+$ breast cancer, and retrospectively examined HER2 gene amplification and TP53 mutation in breast cancer tissues in patients with or without early recurrence. Post-relapse survival in patients with early recurrence was also analyzed by mutation status of HER2 and TP53. Results: Surprisingly, amplification of the HER2 gene was found in $15 \%$ of patients with early recurrence. None of the patients without relapse had HER2-amplified tumors. Post-relapse survival in patients with HER2 gene amplification and/or TP53 mutation in primary tumors was shorter than that in patients without these mutations, especially among postmenopausal women. Conclusion: HER2 gene amplification exists in ER-positive, HER2 IHC O or 1+ breast cancer in patients who developed early distant metastasis.
\end{abstract}

Endocrine therapy is the most important treatment option for women with estrogen receptor (ER)-positive breast cancer $(1,2)$. We and others have previously reported that tumor grade and/or Ki67 expression are predictors of early

This article is freely accessible online.

Correspondence to: Hiroko Yamashita, Department of Breast Surgery, Hokkaido University Hospital, Kita 14, Nishi 5, Kita-ku, Sapporo 060-8648, Japan. Tel: +81 117067381, Fax: +81 117067384,e-mail: hirokoy@huhp.hokudai.ac.jp

Key Words: Breast cancer, HER2 gene amplification, TP53 mutation, estrogen receptor, early recurrence. recurrence in ER-positive, human epidermal growth factor receptor 2 (HER2)-negative breast cancer (3-5). Adjuvant chemotherapy has proven to be effective in reducing the risk of early recurrence, which is defined as relapse within the first 5 years after diagnosis (6). Nevertheless, our previous study revealed that approximately two thirds of patients with ER-positive, HER2-negative breast cancer who relapsed within 5 years had received anthracyclines and/or taxanes as adjuvant or neoadjuvant chemotherapy (3). These standard chemotherapies as well as adjuvant endocrine therapy might not be enough for prevention of early relapse. Furthermore, our previous study also indicated short post-relapse survival in patients with early recurrence (7).

The HER2 gene is amplified and/or overexpressed in approximately $15 \%$ of primary breast cancers (8), and more than half of HER2-positive breast cancers are ER-positive (9). Since 2007, the American Society of Clinical Oncology (ASCO)/College of American Pathologists (CAP) has issued clinical practice guidelines on HER2 testing (10-12). HER2 gene amplification assessed by in situ hybridization (ISH) or protein overexpression assessed by immunohistochemistry (IHC) remains the primary predictor of responsiveness to HER2-targeted therapies in breast cancer. A previous study reported that a large percent of tumors with $H E R 2$ gene amplification by ISH showed a HER2 IHC score of 0 or $1+$, although the concordance rate of HER2 testing by IHC and ISH was more than $95 \%$ (13). In clinical practice, tumors with HER2 IHC 0 or $1+$ have not been tested for amplification by ISH. Therefore, the clinical significance for HER2 gene amplification in HER2-non-overexpressing (score 0 or $1+$ ) breast cancer has not been identified. On the other hand, some patients with ER-positive, HER2 IHC 0 or 1+ primary tumors develop early relapse with HER2-positive metastasis. In these cases, HER2 gene amplification might have existed in the primary tumors. 
The TP53 gene is the most frequently mutated gene in cancer, including breast cancer (14). A TP53 gene mutation has been found to be present in $12 \%$ of luminal $\mathrm{A}$ and $32 \%$ of luminal B breast cancers, although the frequency of TP53 gene mutations in luminal tumors is lower compared to basal-like $(84 \%)$ or HER2-positive $(75 \%)$ breast cancers (14). Functional p53 plays an important role in maintaining genomic stability, regulating the cell cycle and inducing apoptosis (15). Since mutated p53 accumulates in the nucleus of tumor cells, IHC staining for p53 is frequently used as a surrogate marker for TP53 mutational status. The association between overexpression of p53 and poor prognosis has been reported in premenopausal breast cancer patients treated with tamoxifen after chemotherapy (16). A recent study has also demonstrated that TP53 wild-type status conferred superior 5-year overall survival in patients treated with adjuvant endocrine therapy (17). We previously reported that $20 \%$ of ER-positive breast cancer patients showed p53 accumulation by IHC (18), and that p53 accumulation predicted resistance to endocrine therapy and decreased post-relapse survival in metastatic breast cancer (19). We also demonstrated that p53 accumulation was a strong predictor, especially of early recurrence in postmenopausal ER-positive breast cancer $(20,21)$.

We hypothesized HER2 gene amplification and/or TP53 mutation might exist in some ER-positive, HER2 IHC 0 or $1+$ breast cancer patients who developed early distant recurrence. In this study, we retrospectively examined HER2 gene amplification and TP53 mutation in ER-positive, HER2 IHC 0 or $1+$ primary breast cancer in patients who relapsed within five years after initial treatment.

\section{Materials and Methods}

Patients and breast cancer tissues. A total of 27 consecutive women with ER-positive, HER2 IHC 0 or 1+ breast cancer who relapsed with distant metastasis within five years after initial treatment were recruited to this study (Table I). All patients had undergone breast surgery for Stage I to III breast cancer between 2002 and 2011 at Hokkaido University Hospital. For each recurrence patient, approximately one age-matched control patient without relapse for more than six years who was initially treated in 2011, was randomly selected using RAND in combination with Excel software. The study protocol was approved by the institutional review board and conformed to the guidelines of the 1996 Declaration of Helsinki. Written informed consent for the use of surgically resected tumor tissues was provided by all patients prior to treatments. All patients had undergone mastectomy or lumpectomy. Patients who were positive for axillary lymph nodes received neoadjuvant or adjuvant chemotherapy. Pretreatment specimens obtained by core needle biopsies were used for IHC and mutation analyses in patients treated with neoadjuvant chemotherapy. Of the remaining patients, tumor samples were obtained during surgery. As standard adjuvant systemic treatment, all patients received endocrine therapy. Patients with positive axillary lymph nodes and/or high-grade tumors received preor post-operative chemotherapies including anthracyclines and taxanes or TC (docetaxel and cyclophosphamide), as well as adjuvant endocrine therapy.

Immunohistochemical analysis. IHC status of ER, progesterone receptor $(\mathrm{PgR})$, and HER2 was determined using the PATHWAY rabbit monoclonal antibodies (clone SP1, 1E2, and 4B5, respectively) and iView DAB Detection Kit (Ventana Medical Systems, Inc., Tucson, AZ, USA) (22). Tumors with $\geq 1 \%$ of cells showing positive nuclear staining for the expression of ER and PgR were evaluated as ER/PgR-positive (23). To determine the level of HER 2 expression, the membrane staining pattern was estimated and scored on a scale of 0 to $3+(12)$. Tumors with a score of 0 or $1+$ were recruited in this study. For Ki67 and p53 staining, antigens were retrieved in Dako EnVision FLEX Target Retrieval Solution, high pH (pH9.0) using Dako PT Link (Dako, Glostrup, Denmark) $(20,21)$. IHC for Ki67 was performed using a mouse monoclonal anti-human Ki67 antibody (MIB-1, Dako) and the Dako Envision FLEX system was used for visualization $(20,21)$. The labeling index (LI) was assessed as the percentage of tumor cells showing definite nuclear staining among $>1000$ invasive tumor cells (24). IHC for p53 was performed using a mouse monoclonal anti-human p53 antibody (DO-7, Dako) with the Dako Envision FLEX system for visualization. Expression of p53 protein was measured as the percentage of cells showing definite nuclear staining $(20,21)$. Three researchers including two pathologists (N.I., H.K-O. and K.C.H) who were blinded to the clinical information of patients independently examined and scored each case. Differences in interpretation were resolved by the consensus agreements of these three researchers.

HER2 gene testing by dual color in situ hybridization. HER2 gene testing by dual color in situ hybridization (DISH) was performed with the invasive cancer nests stained most strongly by IHC (25). Hybridization was performed using an Inform HER2 Dual ISH DNA Probe Cocktail (Ventana Medical Systems). Hapten labeling of the HER2 gene was visualized with an UltraView SISH DNP Detection Kit (Ventana Medical Systems), and hapten labeling of CEP17 was visualized with an UltraView Red ISH DIG Detection Kit (Ventana Medical Systems). Signal counting in DISH was performed in accordance with the Interpretation Guide for the Ventana Inform HER2 Dual ISH DNA Probe Cocktail Assay. HER2 gene amplification status was classified according to the ASCO/CAP guidelines for HER2 testing $(11,12)$. HER2 gene and CEP17 signals were counted for 20 cancer cells, and HER2/CEP17 ratio $\geq 2.0$ with an average $H E R 2$ copy number $\geq 4.0$ signals per cell were taken to indicate HER 2 gene amplification. HER2/CEP17 ratio $<2.0$ with an average $H E R 2$ copy number $<4.0$ signals per cell was considered to indicate $H E R 2$ gene non-amplification. HER2/CEP17 ratio $<2.0$ with an average HER 2 copy number $\geq 6.0$ signals per cell indicated HER2 gene amplification.

TP53 mutation analysis. Genomic DNA was extracted from formalin-fixed paraffin-embedded tumor blocks using the QIAamp DNA FFPE Tissue Kit (QIAGEN, Hilden, Germany). Four to eight pieces of a deparaffinized $10 \mu \mathrm{m}$ section were used for the extraction process. The amount of genomic DNA was spectrophotometrically determined (NanoDrop 2000c, Thermo Fisher Scientific, Waltham, MA, USA) before use.

The TP53 gene was amplified by means of polymerase chain reaction using primers for exons 5-9 as described in the detection 
Table I. Comparison of clinicopathological characteristics and treatments between patients with early and no recurrence.

\begin{tabular}{|c|c|c|c|}
\hline & Early recurrence $(n=27)$ & No recurrence $(n=29)$ & $p$-Value \\
\hline Age (at the time of the initial therapy), mean \pm SD (range) & $53.6 \pm 10.2(35-74)$ & $57.3 \pm 10.3(35-78)$ & 0.61 \\
\hline \multicolumn{4}{|l|}{ Menopausal status (at the time of the initial therapy) } \\
\hline Premenopausal & $9(33 \%)$ & $10(34 \%)$ & \multirow[t]{2}{*}{0.93} \\
\hline Postmenopausal & $18(67 \%)$ & $19(66 \%)$ & \\
\hline \multicolumn{4}{|l|}{ Tumor category } \\
\hline $\mathrm{T} 1$ & $13(48 \%)$ & $20(69 \%)$ & \multirow[t]{3}{*}{$0.04 *$} \\
\hline $\mathrm{T} 2$ & $9(33 \%)$ & $9(31 \%)$ & \\
\hline $\mathrm{T} 3$ & $5(19 \%)$ & $0(0 \%)$ & \\
\hline \multicolumn{4}{|l|}{ Lymph node status } \\
\hline pNO & $17(63 \%)$ & $15(52 \%)$ & \multirow[t]{2}{*}{0.40} \\
\hline pN1-pN3 & $10(37 \%)$ & $14(48 \%)$ & \\
\hline \multicolumn{4}{|l|}{ Tumor grade } \\
\hline 1 & $7(26 \%)$ & $14(48 \%)$ & \multirow[t]{3}{*}{0.05} \\
\hline 2 & $14(52 \%)$ & $14(48 \%)$ & \\
\hline 3 & $6(22 \%)$ & $1(4 \%)$ & \\
\hline $\mathrm{ER}(\%)$, mean $\pm \mathrm{SD}$ (range) & $54.8 \pm 36.8(1-100)$ & $98.8 \pm 3.2(90-100)$ & $<0.001^{*}$ \\
\hline $\operatorname{PgR}(\%)$, mean $\pm \mathrm{SD}$ (range) & $28.6 \pm 39.5(0-100)$ & $55.3 \pm 40.5(0-100)$ & 0.08 \\
\hline \multicolumn{4}{|l|}{ HER2 IHC score } \\
\hline 0 & $16(59 \%)$ & $20(69 \%)$ & \multirow[t]{2}{*}{0.45} \\
\hline $1+$ & $11(41 \%)$ & $9(31 \%)$ & \\
\hline \multicolumn{4}{|l|}{ HER2 gene amplification } \\
\hline Present & $4(15 \%)$ & $0(0 \%)$ & \multirow[t]{2}{*}{$0.048^{*}$} \\
\hline Absent & $23(85 \%)$ & $29(100 \%)$ & \\
\hline Ki67 LI (\%), mean \pm SD (range) & $19.8 \pm 12.7(4-44.4)$ & $17.2 \pm 11.4(1.9-45.5)$ & 0.51 \\
\hline p53 protein $(\%)$, mean \pm SD (range) & $19.5 \pm 32.4(0-100)$ & $15.3 \pm 24.6(0-95)$ & 0.84 \\
\hline $\mathrm{p} 53<10 \%$ & $18(67 \%)$ & $19(66 \%)$ & 0.93 \\
\hline $\mathrm{p} 53 \geq 10 \%$ & $9(33 \%)$ & $10(34 \%)$ & \\
\hline \multicolumn{4}{|l|}{ TP53 mutation } \\
\hline Present & $6(23 \%)$ & $7(26 \%)$ & \multirow[t]{3}{*}{0.81} \\
\hline Absent & $20(77 \%)$ & $20(74 \%)$ & \\
\hline Invalid & 1 & 2 & \\
\hline \multicolumn{4}{|l|}{ Neoadjuvant/adjuvant chemotherapy } \\
\hline Yes & $12(44 \%)$ & $8(28 \%)$ & \multirow[t]{2}{*}{0.19} \\
\hline No & $15(56 \%)$ & $21(72 \%)$ & \\
\hline \multicolumn{4}{|l|}{ Adjuvant endocrine therapy } \\
\hline Yes & $24(89 \%)$ & $29(100 \%)$ & \multirow[t]{3}{*}{0.07} \\
\hline No & $3(11 \%)$ & $0(0 \%)$ & \\
\hline Follow-up time, mean \pm SD (range) (months) & $72.7 \pm 41.6(14-146)$ & $63.0 \pm 5.8(40-70)$ & \\
\hline
\end{tabular}

${ }^{*} p<0.05$ is considered significant.

of TP53 mutations by direct sequencing [IARC protocol (26)]. Amplification was performed using MightyAmp DNA Polymerase Ver. 2 (Takara Bio Inc., Kusatsu, Japan). PCR samples were purified with the ExoSAP-IT PCR Product Cleanup Reagent (Thermo Fisher Scientific, Tokyo, Japan). Direct sequencing was performed using each of the primers and the BigDye Terminator v3.1 Cycle Sequencing Kit (Thermo Fisher Scientific). After purification of the samples with the BigDye XTerminator Purification Kit (Thermo Fisher Scientific), DNA sequencing was carried out using the 3730xl DNA Analyzer (Thermo Fisher Scientific).

Statistical analysis. The chi-squared test, Student's $t$-test and the Mann-Whitney $U$-test were used to compare clinicopathological characteristics and treatments among patients with early and no recurrence. Estimation of post-relapse survival was performed using the Kaplan-Meier method, and differences between survival curves were assessed using the log-rank test. Cox's proportional hazards model was used for univariate and multivariate analyses of prognostic values. Statistical analysis was performed using Excel software (Microsoft corp., Albuquerque, MX, USA).

\section{Results}

Comparison of clinicopathological characteristics and treatments between patients with early and no distant recurrence. We collected data from a total of 27 women with early distant recurrence and 29 women without relapse for more than six years, all of whom had ER-positive, HER2 IHC 0 or $1+$ breast cancer (Table I). Patients with early recurrence had larger clinical tumor size than those without recurrence $(p=0.04)$. Expression levels of ER were 
Table II. Tumor characteristics of four patients with HER2 gene amplification without HER2 overexpression.

\begin{tabular}{lccccccrr}
\hline $\begin{array}{l}\text { Patient } \\
\text { no. }\end{array}$ & $\begin{array}{c}\text { HER2/CEP17 } \\
\text { ratio }\end{array}$ & $\begin{array}{c}\text { Average HER2 copy } \\
\text { number per cell }\end{array}$ & $\begin{array}{c}\text { HER2 IHC } \\
\text { score }\end{array}$ & $\begin{array}{c}\text { TP53 } \\
\text { mutation }\end{array}$ & $\begin{array}{c}\text { p53 } \\
\text { protein }\end{array}$ & $\begin{array}{c}\text { Ki67 } \\
\text { LI }\end{array}$ & $\begin{array}{c}\text { ER } \\
\text { Recurrence } \\
\text { status }\end{array}$ \\
\hline 18 & 2.0 & 4.3 & $1+$ & $\begin{array}{c}\text { G262S } \\
\text { Missense }\end{array}$ & $1 \%$ & $10 \%$ & $3 \%$ & Early recurrence \\
3 & 2.3 & 4.5 & 0 & Wild-type & $5 \%$ & $4 \%$ & $90 \%$ & Early recurrence \\
16 & 2.3 & 4.9 & $1+$ & S313N & $5 \%$ & $20 \%$ & $70 \%$ & Early recurrence \\
8 & 3.2 & 6.8 & $1+$ & Missense & $3 \%$ & $18 \%$ & $1 \%$ & Early recurrence \\
\hline
\end{tabular}

Table III. Tumor characteristics of thirteen patients with TP53 mutations.

\begin{tabular}{|c|c|c|c|c|c|c|c|c|c|}
\hline $\begin{array}{l}\text { Patient } \\
\text { no. }\end{array}$ & Exon & $\begin{array}{l}\text { Nucleotide } \\
\text { change }\end{array}$ & $\begin{array}{l}\text { Amino acid } \\
\text { change }\end{array}$ & $\begin{array}{l}\text { Mutation } \\
\text { type }\end{array}$ & $\begin{array}{c}\mathrm{p} 53 \\
\text { protein }\end{array}$ & $\begin{array}{c}\text { Ki67 } \\
\text { LI }\end{array}$ & $\begin{array}{c}H E R 2 \\
\text { amplification }\end{array}$ & ER & $\begin{array}{l}\text { Recurrence } \\
\text { status }\end{array}$ \\
\hline \multicolumn{10}{|c|}{ Single mutation } \\
\hline 33 & 5 & c. $424 \mathrm{G}>\mathrm{A}$ & P142S & Missense & $2 \%$ & $8 \%$ & Non-amplified & $100 \%$ & No recurrence \\
\hline 37 & 5 & c. $430 \mathrm{G}>\mathrm{A}$ & Q144* & Nonsense & $25 \%$ & $15 \%$ & Non-amplified & $100 \%$ & No recurrence \\
\hline 51 & 5 & c. $489 \mathrm{G}>\mathrm{A}$ & Y163 & Silent & $1 \%$ & $11 \%$ & Non-amplified & $100 \%$ & No recurrence \\
\hline 21 & 8 & c. $839 \mathrm{G}>\mathrm{C}$ & $\mathrm{R} 280 \mathrm{~T}$ & Missense & $100 \%$ & $37 \%$ & Non-amplified & $100 \%$ & Early recurrence \\
\hline 35 & 9 & c. $920 \mathrm{G}>\mathrm{C}$ & A307G & Missense & $8 \%$ & $18 \%$ & Non-amplified & $100 \%$ & No recurrence \\
\hline 16 & 9 & c. $.938 \mathrm{C}>\mathrm{T}$ & S313N & Missense & $5 \%$ & $20 \%$ & Amplified & $70 \%$ & Early recurrence \\
\hline 27 & 9 & c. $971 \mathrm{G}>\mathrm{A}$ & Q331* & Nonsense & $100 \%$ & $44 \%$ & Non-amplified & $10 \%$ & Early recurrence \\
\hline \multicolumn{10}{|c|}{ Double mutations } \\
\hline \multirow[t]{2}{*}{52} & 6 & c.594delC & E198 & Frameshift & $3 \%$ & $14 \%$ & Non-amplified & $90 \%$ & No recurrence \\
\hline & 6 & c.600delA & N200 & Frameshift & & & & & \\
\hline \multirow[t]{2}{*}{18} & 8 & c. $784 \mathrm{G}>\mathrm{A}$ & G262S & Missense & $1 \%$ & $10 \%$ & Amplified & $3 \%$ & Early recurrence \\
\hline & 8 & c. $829 \mathrm{~T}>\mathrm{C}$ & $\mathrm{C} 277$ & Silent & & & & & \\
\hline \multirow[t]{2}{*}{47} & 8 & c. $814 \mathrm{C}>\mathrm{T}$ & V272M & Missense & $95 \%$ & $23 \%$ & Non-amplified & $100 \%$ & No recurrence \\
\hline & 8 & c. $859 \mathrm{C}>\mathrm{T}$ & E287K & Missense & & & & & \\
\hline \multicolumn{10}{|c|}{ Triple mutations } \\
\hline \multirow[t]{3}{*}{17} & 5 & c. $425 \mathrm{G}>\mathrm{T}$ & $\mathrm{P} 142 \mathrm{H}$ & Missense & $30 \%$ & $21 \%$ & Non-amplified & $100 \%$ & Early recurrence \\
\hline & 5 & c. $432 \mathrm{C}>\mathrm{G}$ & Q144H & Missense & & & & & \\
\hline & 8 & c. $813 \mathrm{C}>\mathrm{T}$ & E271 & Silent & & & & & \\
\hline \multirow[t]{3}{*}{49} & 5 & c. $550 \mathrm{G}>\mathrm{A}$ & D184N & Missense & $25 \%$ & $25 \%$ & Non-amplified & $100 \%$ & No recurrence \\
\hline & 7 & c. $696 \mathrm{C}>\mathrm{T}$ & $\mathrm{I} 232$ & Silent & & & & & \\
\hline & 7 & c. $729 \mathrm{G}>\mathrm{C}$ & M243I & Missense & & & & & \\
\hline \multirow[t]{3}{*}{2} & 7 & c. $694 \mathrm{~A}>\mathrm{G}$ & $\mathrm{I} 232 \mathrm{~V}$ & Missense & $5 \%$ & $4 \%$ & Non-amplified & $40 \%$ & Early recurrence \\
\hline & 7 & c. $718 \mathrm{G}>\mathrm{C}$ & S240T & Missense & & & & & \\
\hline & 7 & c. $746 \mathrm{G}>\mathrm{T}$ & $\mathrm{R} 249 \mathrm{M}$ & Missense & & & & & \\
\hline
\end{tabular}

significantly lower in patients with early recurrence than in those without relapse $(p<0.001)$.

HER2 gene amplification in breast cancer tissues without HER 2 overexpression. We examined HER2 gene amplification in 56 HER2 non-overexpressing (IHC 0 or 1+) tumors from patients with or without early recurrence. Surprisingly, DISH confirmed amplification of the HER2 gene in four tumors, and all four patients with $H E R 2$-amplified tumors relapsed within five years after initial treatment (Tables I and II). Thus, four
(15\%) of the 27 patients with early distant recurrence had HER2-amplified tumors in ER-positive, HER2 IHC 0 or 1+ breast cancer. Of the four tumors with HER2 gene amplification, HER2/CEP17 ratio was 2.0 to 3.2, and average HER2 copy number per cell was 4.3 to 6.8 (Table II). TP53 missense mutations were also detected in two tumors (G262S and $\mathrm{S} 313 \mathrm{~N}$, respectively). In contrast, p53 expression was less than $10 \%$ in all four HER2-amplified tumors. The Ki67 LI was $4 \%$ to $20 \%$, and expression levels of ER were $3 \%$ to $90 \%$ in these four HER2-amplified tumors. 

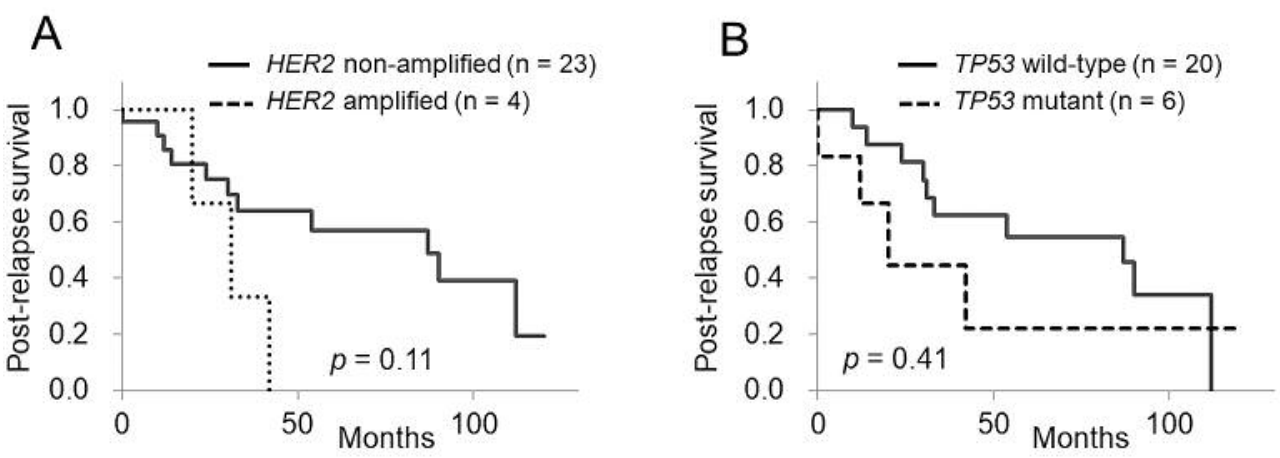

Figure 1. Kaplan-Meier curves of the effect of HER2 gene amplification (A) and TP53 mutation (B) on post-relapse survival in postmenopausal women with early recurrence.

TP53 mutations in breast cancer tissues. We next evaluated the genomic DNA of primary breast cancer specimens for TP53 mutations. Specimens from one tumor with early recurrence and two tumors without relapse were invalid. Of the 53 tumors that we were able to evaluate, seven tumors had a single mutation, three tumors had mutations at two sites, and three tumors had mutations at three sites (Table III). All of the mutations were present at different sites. Of the 22 mutations, 14 were missense, four were silent, two were nonsense, and two were frameshift mutations. Ki67 LI values were from $4 \%$ to $44 \%$ (median $18 \%$ ) and expression levels of ER ranged from $3 \%$ to $100 \%$ (median 100\%) in TP53-mutant tumors. Among the thirteen patients with TP53-mutant tumors, six patients relapsed within 5 years and seven patients remained disease-free. TP53 mutation status did not differ between patients with early distant recurrence and those without recurrence (Table I).

Of the 53 tumors with and without TP53 mutations, p53 expression was significantly higher in TP53-mutant tumors $(\mathrm{n}=13)$ than in TP53-wild-type tumors $(\mathrm{n}=40)($ mean $\pm \mathrm{SD}$ $30.8 \% \pm 40.0 \%$ versus $11.8 \% \pm 20.0 \%$, mutant versus wild-type, $p=0.001$ ). However, expression levels of p53 varied from $1 \%$ to $100 \%$ in TP53-mutant tumors (Table III). Moreover, p53 expression did not differ between patients with early distant recurrence and those without recurrence (Table I).

Post-relapse survival according to HER2 and TP53 status in patients with early recurrence. We then analyzed whether HER2 gene amplification and TP53 mutation affected postrelapse survival in patients with early distant recurrence. Median post-relapse survival in patients with HER2-nonamplified and HER2-amplified tumors were 33 months and 25.5 months, whereas median post-relapse survival in patients with TP53-wild-type and TP53-mutant tumors were 36.5 months and 17 months, respectively (Table IV). Kaplan-Meier analysis showed that patients with HER2amplified tumors had shorter post-relapse survival compared
Table IV. Post-relapse survival according to HER2 gene and TP53 status in patients with early recurrence.

\begin{tabular}{lcc}
\hline & $\begin{array}{c}\text { No. of } \\
\text { patients }\end{array}$ & $\begin{array}{c}\text { Post-relapse survival, } \\
\text { median (range) (months) }\end{array}$ \\
\hline $\begin{array}{l}\text { All patients } \\
\text { HER2 gene amplification }\end{array}$ & 27 & $31(0-120)$ \\
$\begin{array}{l}\text { Non-amplified } \\
\text { Amplified }\end{array}$ & $23(85 \%)$ & $33(0-120)$ \\
TP53 mutation* & $4(15 \%)$ & $25.5(9-42)$ \\
Wild-type & $20(77 \%)$ & $36.5(0-112)$ \\
Mutant & $6(23 \%)$ & $17(0-120)$ \\
\hline
\end{tabular}

*One tumor was invalid.

to those with HER2-non-amplified tumors (Figure 1A). Moreover, patients with TP53-mutant tumors had shorter post-relapse survival compared to those with TP53-wild-type tumors (Figure 1B). In 18 postmenopausal patients with early relapse, one tumor was invalid for TP53 mutation analysis. Univariate analysis demonstrated a significant association between decreased post-relapse survival and low ER expression ( $p=0.045)$, presence of TP53 mutation and/or HER2 amplification $(p=0.02)$ and short total duration of endocrine therapies after relapse $(p=0.04)$ (Table V). However, presence of TP53 mutation or HER2 amplification was not significantly correlated with post-relapse survival. In multivariate analysis, the presence of TP53 mutation and/or HER2 amplification was the only prognostic factor for decreased post-relapse survival in postmenopausal patients with early distant recurrence $(p=0.02$, Table V).

\section{Discussion}

In this study, we focused on ER-positive, HER2 IHC 0 or 1+ breast cancer patients who relapsed within five years after initial treatment. Assessment of HER2 protein expression by 
Table V. Univariate and multivariate analyses of factors predicting post-relapse survival in postmenopausal patients with early recurrence.

\begin{tabular}{|c|c|c|c|c|c|c|}
\hline & \multicolumn{3}{|c|}{ Univariate } & \multicolumn{3}{|c|}{ Multivariate } \\
\hline & HR & $95 \% \mathrm{CI}$ & $p$-Value & $\mathrm{HR}$ & $95 \% \mathrm{CI}$ & $p$-Value \\
\hline Age & 0.91 & $0.77-1.07$ & 0.25 & & & \\
\hline Tumor category & 1.23 & $0.53-2.89$ & 0.63 & & & \\
\hline Lymph node status & 1.06 & $0.99-1.14$ & 0.10 & & & \\
\hline Tumor grade & 1.07 & $0.37-3.08$ & 0.90 & & & \\
\hline $\mathrm{ER}(\%)$ & 0.97 & $0.95-0.99$ & $0.045^{*}$ & 0.96 & $0.93-1.00$ & 0.05 \\
\hline Ki67 LI (\%) & 1.03 & $0.96-1.09$ & 0.47 & & & \\
\hline p53 protein $(\%)$ & 1.00 & $0.98-1.03$ & 0.72 & & & \\
\hline Presence of TP53 mutation & 1.65 & $0.50-5.45$ & 0.41 & & & \\
\hline Presence of $H E R 2$ amplification & 2.90 & $0.74-11.32$ & 0.12 & & & \\
\hline Presence of TP53 mutation and/or HER2 amplification & 8.41 & $1.35-52.3$ & $0.02 *$ & 20.4 & $1.55-268$ & $0.02 *$ \\
\hline Neoadjuvant/adjuvant chemotherapy & 1.36 & $0.34-5.47$ & 0.66 & & & \\
\hline Disease-free interval & 1.06 & $1.00-1.13$ & 0.07 & & & \\
\hline Duration of first-line endocrine therapy & 1.00 & $0.95-1.04$ & 0.85 & & & \\
\hline Total duration of endocrine therapies after relapse (months) & 0.97 & $0.95-0.99$ & $0.04 *$ & 0.98 & $0.96-1.01$ & 0.24 \\
\hline
\end{tabular}

$* p<0.05$ is considered significant.

IHC might vary according to tissue handling including fixation, the operating procedure, and the evaluation method (10). Moreover, a large percent of tumors without HER2 protein overexpression (IHC score 0 or $1+$ ) have HER 2 gene amplification $(13,27,28)$. However, the clinical significance of HER2 gene amplification in HER2-non-overexpressing breast cancer has not been identified. Because tumors with HER2 IHC 0 or $1+$ are not tested for amplification by ISH in clinical practice, anti-HER2 treatments are not administered to patients with HER2 gene amplification without HER2 overexpression. In the present study, $H E R 2 / \mathrm{CEP} 17$ ratios and average HER2 copy numbers per cell were not very high (2.0-3.2 and 4.3-6.8, respectively) in all four HER2-amplified tumors. The $\mathrm{Ki} 67 \mathrm{LI}$ was $4 \%$ to $20 \%$ in four tumors with HER2 gene amplification, indicating that the risk of early recurrence was probably low (3). On the other hand, expression levels of ER were very low (1\% and 3\%, respectively) in two HER2-amplified tumors. Although the sample size of this study is small, ERpositive tumors with HER2 gene amplification, HER2 IHC 0 or $1+$ breast cancer are present especially in patients with early recurrence. Moreover, not just early relapse, but also shorter post-relapse survival was observed in patients with HER2 gene amplification, suggesting that endocrine therapies and chemotherapies might not have been effective for early and metastatic breast cancers. Since these patients were treated as having HER2-negative breast cancer, antiHER2 therapies were not given. It is not clear whether HER2 IHC 0 or $1+$ breast cancer with HER 2 gene amplification responds to adjuvant anti-HER2 therapy. A re-biopsy against the metastatic sites to examine HER2 protein overexpression and/or multigene panel testing of the primary or metastatic sites might be useful when planning treatment options for ER-positive, HER2-negative metastatic breast cancer, especially in the context of early recurrence.

In this study, we also examined TP53 mutation in primary breast cancer tissues with ER-positive and HER2 IHC 0 or $1+$ breast cancer. We previously demonstrated that p53 accumulation was correlated with an aggressive phenotype, such as high tumor grade and high Ki67 expression, and that p53 accumulation was a strong predictor of both early and late recurrence in ER-positive breast cancer patients treated with aromatase inhibitors as adjuvant endocrine therapy (20, 21). The correlation between p53 accumulation measured by IHC and TP53 mutation detected by sequencing has been estimated to be less than $75 \%$ in breast cancer (29). Not all mutations yield a stable protein and some mutations lead to a truncated protein not detected by IHC. Done and colleagues demonstrated strong p53 nuclear staining in all tumors known to have missense mutations but in none of the tumors with truncation mutations (30). On the other hand, wild-type p53 may accumulate in some tumors in response to DNA damage or by binding to other cellular proteins, giving a positive IHC result (15). Our present study showed that TP53 mutations in breast cancer tissues were present both in patients with early relapse and in patients without recurrence, and expression levels of the p53 protein were significantly higher in TP53 mutant tumors than in TP53 wild-type tumors. It is not clear whether mutations of the TP53 gene present in a primary tumor function as a driver for progression of breast cancer. Uji and colleagues analyzed TP53 mutation both by next-generation sequencing and Sanger sequencing and the TP53 mutation-associated gene expression signature by DNA microarray in 115 ER-positive 
breast cancers (31). They reported that next-generation sequencing was more sensitive in the detection of TP53 mutations than Sanger sequencing, and that only the TP53 mutation-associated gene expression signature proved to be a powerful prognostic indicator. On the other hand, our present study showed that post-relapse survival was significantly worse in postmenopausal patients with HER2 gene amplification and/or TP53 mutation compared to that in patients without these mutations. In addition to HER2 gene amplification, TP53 gene alteration might be a key biological characteristic of ER-positive breast cancer.

In conclusion, HER2 gene amplification exists in ERpositive, HER2 IHC 0 or $1+$ breast cancer in patients who developed early distant metastasis. Post-relapse survival in patients with HER2 gene amplification and/or TP53 mutation in primary tumors was found to be shorter than in patients without these mutations, especially among postmenopausal women. A re-biopsy of the metastatic sites to examine HER2 protein overexpression and/or multigene panel testing of the primary or metastatic sites might be useful when planning treatment options for ER-positive, HER2-negative metastatic breast cancer, especially in the context of early recurrence.

\section{Conflicts of Interest}

All Authors declare no conflicts of interest regarding this study.

\section{Authors' Contributions}

HY conceived of the study, analyzed the data, and participated in manuscript writing. NI carried out experiments and analyzed the data. $\mathrm{YH}$ and $\mathrm{KCH}$ carried out mutation experiments. $\mathrm{KH}$, TO and TT provided tissue samples and clinical data. HK-O, AS, KCH and YM carried out immunostaining experiments. All Authors read and approved the final manuscript.

\section{References}

1 Davies C, Godwin J, Gray R, Clarke M, Cutter D, Darby S, McGale P, Pan HC, Taylor C, Wang YC, Dowsett M, Ingle J and Peto R: Relevance of breast cancer hormone receptors and other factors to the efficacy of adjuvant tamoxifen: patient-level metaanalysis of randomised trials. Lancet 378(9793): 771-784, 2011. PMID: 21802721. DOI: 10.1016/S0140-6736(11)60993-8

2 Dowsett M, Forbes JF, Bradley R, Ingle J, Aihara T, Bliss J, Boccardo F, Coates A, Coombes RC, Cuzick J, Dubsky P, Gnant M, Kaufmann M, Kilburn L, Perrone F, Rea D, Thurlimann B, van de Velde C, Pan H, Peto R, Davies C and Gray R: Aromatase inhibitors versus tamoxifen in early breast cancer: patient-level meta-analysis of the randomised trials. Lancet 386(10001): 1341-1352, 2015. PMID: 26211827. DOI: 10.1016/S0140-6736(15)61074-1

3 Yamashita H, Ogiya A, Shien T, Horimoto Y, Masuda N, Inao T, Osako T, Takahashi M, Endo Y, Hosoda M, Ishida N, Horii R, Yamazaki K, Miyoshi Y, Yasojima $\mathrm{H}$ and Tomioka N: Clinicopathological factors predicting early and late distant recurrence in estrogen receptor-positive, HER2-negative breast cancer. Breast Cancer 23(6): 830-843, 2016. PMID: 26467036. DOI: $10.1007 / \mathrm{s} 12282-015-0649-0$

4 Sestak I, Dowsett M, Zabaglo L, Lopez-Knowles E, Ferree S, Cowens JW and Cuzick J: Factors predicting late recurrence for estrogen receptor-positive breast cancer. J Natl Cancer Inst 105(19): 1504-1511, 2013. PMID: 24029245. DOI: 10.1093/ jnci/djt244

5 Sestak I and Cuzick J: Markers for the identification of late breast cancer recurrence. Breast Cancer Res 17: 10, 2015. PMID: 25848913. DOI: 10.1186/s13058-015-0516-0

6 Palmieri C and Jones A: The 2011 EBCTCG polychemotherapy overview. Lancet 379(9814): 390-392, 2012. PMID: 22152852. DOI: 10.1016/S0140-6736(11)61823-0

7 Ogiya A, Yamazaki K, Horii R, Shien T, Horimoto Y, Masuda $\mathrm{N}$, Inao T, Hosoda M, Ishida N, Osako T, Takahashi M, Endo Y, Miyoshi Y, Yasojima H, Tomioka N and Yamashita H: Postrelapse survival in patients with the early and late distant recurrence in estrogen receptor-positive HER2-negative breast cancer. Breast Cancer 24(3): 473-482, 2017. PMID: 27628678. DOI: $10.1007 / \mathrm{s} 12282-016-0730-3$

8 Kurebayashi J, Miyoshi Y, Ishikawa T, Saji S, Sugie T, Suzuki T, Takahashi S, Nozaki M, Yamashita H, Tokuda Y and Nakamura S: Clinicopathological characteristics of breast cancer and trends in the management of breast cancer patients in Japan: Based on the Breast Cancer Registry of the Japanese Breast Cancer Society between 2004 and 2011. Breast Cancer 22(3): 235-244, 2015. PMID: 25758809. DOI: 10.1007/s12282-015-0599-6

9 Hwang KT, Kim J, Jung J, Chang JH, Chai YJ, Oh SW, Oh S, Kim YA, Park SB and Hwang KR: Impact of breast cancer subtypes on prognosis of women with operable invasive breast cancer: a population-based study using SEER database. Clin Cancer Res 25(6): 1970-1979, 2019. PMID: 30559169. DOI: 10.1158/1078-0432.CCR-18-2782

10 Wolff AC, Hammond ME, Schwartz JN, Hagerty KL, Allred DC, Cote RJ, Dowsett M, Fitzgibbons PL, Hanna WM, Langer A, McShane LM, Paik S, Pegram MD, Perez EA, Press MF, Rhodes A, Sturgeon C, Taube SE, Tubbs R, Vance GH, van de Vijver M, Wheeler TM and Hayes DF: American Society of Clinical Oncology/College of American Pathologists guideline recommendations for human epidermal growth factor receptor 2 testing in breast cancer. J Clin Oncol 25(1): 118-145, 2007. PMID: 17159189. DOI: 10.1200/JCO.2006.09.2775

11 Wolff AC, Hammond ME, Hicks DG, Dowsett M, McShane LM, Allison KH, Allred DC, Bartlett JM, Bilous M, Fitzgibbons P, Hanna W, Jenkins RB, Mangu PB, Paik S, Perez EA, Press MF, Spears PA, Vance GH, Viale $G$ and Hayes DF: Recommendations for human epidermal growth factor receptor 2 testing in breast cancer: American Society of Clinical Oncology/College of American Pathologists clinical practice guideline update. J Clin Oncol 31(31): 3997-4013, 2013. PMID: 24101045. DOI: 10.1200/JCO.2013.50.9984

12 Wolff AC, Hammond MEH, Allison KH, Harvey BE, Mangu PB, Bartlett JMS, Bilous M, Ellis IO, Fitzgibbons P, Hanna W, Jenkins RB, Press MF, Spears PA, Vance GH, Viale G, McShane LM and Dowsett M: Human epidermal growth factor receptor 2 testing in breast cancer: American Society of Clinical Oncology/College of American Pathologists Clinical Practice Guideline focused update. J Clin Oncol 36(20): 2105-2122, 2018. PMID: 29846122. DOI: 10.1200/JCO.2018.77.8738 
13 Dennis J, Parsa R, Chau D, Koduru P, Peng Y, Fang Y and Sarode VR: Quantification of human epidermal growth factor receptor 2 immunohistochemistry using the Ventana Image Analysis System: correlation with gene amplification by fluorescence in situ hybridization: the importance of instrument validation for achieving high (>95\%) concordance rate. Am J Surg Pathol 39(5): 624-631, 2015. PMID: 25602790. DOI: 10.1097/PAS.0000000000000375

14 Cancer Genome Atlas Network: Comprehensive molecular portraits of human breast tumours. Nature 490(7418): 61-70, 2012. PMID: 23000897. DOI: 10.1038/nature 11412

15 Lacroix M, Toillon RA and Leclercq G: p53 and breast cancer, an update. Endocr Relat Cancer 13(2): 293-325, 2006. PMID: 16728565. DOI: $10.1677 /$ erc. 1.01172

16 Kim HS, Yom CK, Kim HJ, Lee JW, Sohn JH, Kim JH, Park YL and Ahn SH: Overexpression of p53 is correlated with poor outcome in premenopausal women with breast cancer treated with tamoxifen after chemotherapy. Breast Cancer Res Treat 121(3): 777-788, 2010. PMID: 19806450. DOI: 10.1007/s10549009-0560-5

17 Ungerleider NA, Rao SG, Shahbandi A, Yee D, Niu T, Frey WD and Jackson JG: Breast cancer survival predicted by TP53 mutation status differs markedly depending on treatment. Breast Cancer Res 20(1): 115, 2018. PMID: 30285883. DOI: 10.1186/s13058-018-1044-5

18 Yamashita H, Nishio M, Toyama T, Sugiura H, Zhang Z, Kobayashi $\mathrm{S}$ and Iwase $\mathrm{H}$ : Coexistence of HER2 overexpression and p53 protein accumulation is a strong prognostic molecular marker in breast cancer. Breast Cancer Res 6(1): R2430, 2004. PMID: 14680497. DOI: $10.1186 /$ bcr738

19 Yamashita H, Toyama T, Nishio M, Ando Y, Hamaguchi M, Zhang Z, Kobayashi S, Fujii Y and Iwase H: p53 protein accumulation predicts resistance to endocrine therapy and decreased post-relapse survival in metastatic breast cancer. Breast Cancer Res 8(4): R48, 2006. PMID: 16869955. DOI: 10.1186/bcr 1536

20 Hosoda M, Yamamoto M, Nakano K, Hatanaka KC, Takakuwa E, Hatanaka Y, Matsuno Y and Yamashita H: Differential expression of progesterone receptor, FOXA1, GATA3, and p53 between pre- and postmenopausal women with estrogen receptor-positive breast cancer. Breast Cancer Res Treat 144(2): 249-261, 2014. PMID: 24549642. DOI: 10.1007/s10549-0142867-0

21 Yamamoto M, Hosoda M, Nakano K, Jia S, Hatanaka KC, Takakuwa E, Hatanaka Y, Matsuno Y and Yamashita H: p53 accumulation is a strong predictor of recurrence in estrogen receptor-positive breast cancer patients treated with aromatase inhibitors. Cancer Sci 105(1): 81-88, 2014. PMID: 24118529. DOI: $10.1111 /$ cas.12302

22 Ishida N, Baba M, Hatanaka Y, Hagio K, Okada H, Hatanaka KC, Togashi K, Matsuno Y and Yamashita H: PIK3CA mutation, reduced AKT serine 473 phosphorylation, and increased ERalpha serine 167 phosphorylation are positive prognostic indicators in postmenopausal estrogen receptor-positive early breast cancer. Oncotarget 9(25): 17711-17724, 2018. PMID: 29707142. DOI: $10.18632 /$ oncotarget. 24845

23 Hammond ME, Hayes DF, Dowsett M, Allred DC, Hagerty KL, Badve S, Fitzgibbons PL, Francis G, Goldstein NS, Hayes M, Hicks DG, Lester S, Love R, Mangu PB, McShane L, Miller K, Osborne CK, Paik S, Perlmutter J, Rhodes A, Sasano H,
Schwartz JN, Sweep FC, Taube S, Torlakovic EE, Valenstein P, Viale G, Visscher D, Wheeler T, Williams RB, Wittliff JL and Wolff AC: American Society of Clinical Oncology/College Of American Pathologists guideline recommendations for immunohistochemical testing of estrogen and progesterone receptors in breast cancer. J Clin Oncol 28(16): 2784-2795, 2010. PMID: 20404251. DOI: 10.1200/JCO.2009.25.6529

24 Dowsett M, Nielsen TO, A'Hern R, Bartlett J, Coombes RC, Cuzick J, Ellis M, Henry NL, Hugh JC, Lively T, McShane L, Paik S, Penault-Llorca F, Prudkin L, Regan M, Salter J, Sotiriou C, Smith IE, Viale G, Zujewski JA and Hayes DF: Assessment of Ki67 in breast cancer: recommendations from the International Ki67 in Breast Cancer working group. J Natl Cancer Inst 103(22): 1656-1664, 2011. PMID: 21960707. DOI: 10.1093/jnci/djr393

25 Horii $\mathrm{R}$, Matsuura $\mathrm{M}$, Iwase $\mathrm{T}$, Ito $\mathrm{Y}$ and Akiyama $\mathrm{F}$ : Comparison of dual-color in situ hybridization and fluorescence in-situ hybridization in HER2 gene amplification in breast cancer. Breast Cancer 21(5): 598-604, 2014. PMID: 23307494. DOI: $10.1007 / \mathrm{s} 12282-012-0436-0$

26 International Agency for Research on Cancer (IARC) TP53 Database. Detection of TP53 mutations by Sanger sequencing. Available at: http://p53.iarc.fr/Download/TP53_Sanger Sequencing_IARC.pdf

27 Lambein K, Praet M, Forsyth R, Van den Broecke R, Braems G, Matthys B, Cocquyt V, Denys H, Pauwels P and Libbrecht L: Relationship between pathological features, HER2 protein expression and HER2 and CEP17 copy number in breast cancer: biological and methodological considerations. J Clin Pathol 64(3): 200-207, 2011. PMID: 21177747. DOI: 10.1136/ jcp. 2010.084863

28 Petroni S, Caldarola L, Scamarcio R, Giotta F, Latorre A, Mangia A and Simone G: FISH testing of HER2 immunohistochemistry $1+$ invasive breast cancer with unfavorable characteristics. Oncol Lett 12(5): 3115-3122, 2016. PMID: 27899970. DOI: 10.3892/ol.2016.5125

29 Norberg T, Lennerstrand J, Inganas M and Bergh J: Comparison between p53 protein measurements using the luminometric immunoassay and immunohistochemistry with detection of p53 gene mutations using cDNA sequencing in human breast tumors. Int J Cancer 79(4): 376-383, 1998. PMID: 9699530. DOI: 10.1002/(SICI) 1097-0215(19980821)79:4<376::AID$\mathrm{IJC} 12>3.0 . \mathrm{CO} ; 2-3$

30 Done SJ, Arneson CR, Ozcelik H, Redston M and Andrulis IL: P53 protein accumulation in non-invasive lesions surrounding p53 mutation positive invasive breast cancers. Breast Cancer Res Treat 65(2): 111-118, 2001. PMID: 11261826. DOI: 10.1023/ a: 1006425809069

31 Uji K, Naoi Y, Kagara N, Shimoda M, Shimomura A, Maruyama N, Shimazu K, Kim SJ and Noguchi S: Significance of TP53 mutations determined by next-generation "deep" sequencing in prognosis of estrogen receptor-positive breast cancer. Cancer Lett 342(1): 19-26, 2014. PMID: 23973262. DOI: 10.1016/ j.canlet.2013.08.028

Received January 5, 2020

Revised January 10, 2020

Accepted January 14, 2020 